\title{
Pollen feeding by syrphids varies across seasons in a Mediterranean landscape dominated by the olive orchard
}

\author{
María Villa ${ }^{\mathrm{a}}$, Sónia A.P. Santos ${ }^{\mathrm{b}, \mathrm{c}}$, José Antonio López-Sáez ${ }^{\mathrm{d}}$, Lara Pinheiro ${ }^{\mathrm{a}}$, Rosalina Marrão ${ }^{\mathrm{a}}$, \\ Carlos Aguiara ${ }^{a}$, José Alberto Pereira ${ }^{a, *}$ \\ ${ }^{a}$ Centro de Investigação de Montanha (CIMO), Instituto Politécnico de Bragança, Campus Sta Apolónia, 5300-253 Bragança, Portugal \\ ${ }^{\mathrm{b}}$ CIQuiBio, Barreiro School of Technology, Polytechnic Institute of Setúbal, Rua Américo da Silva Marinho, 2839-001 Lavradio, Portugal \\ ${ }^{\mathrm{c}}$ Linking Landscape, Environment, Agriculture and Food (LEAF), Instituto Superior de Agronomia, Universidade de Lisboa, Tapada da Ajuda, 1349-017 Lisboa, Portugal \\ d GI Arqueobiología, Instituto de Historia, CCHS, CSIC, Albasanz 26-28, 28037 Madrid, Spain
}

\section{H I G H L I G H T S}

- Sphaerophoria scripta and Melanostoma mellinum were the most abundant syrphids.

- Sphaerophoria scripta was associated to olive groves.

- Melanostoma mellinum was associated to herbaceous/scrubland patches.

- In spring, food resources of gravid females differed from non-gravid and males.

- Asteraceae and Plantago pollen type were relevant for gravid females.

\section{A R T I C L E I N F O}

\section{Keywords:}

Egg production

Food resources

Melanostoma mellinum

Olea europaea

Sphaerophoria scripta

\begin{abstract}
A B S T R A C T
Syrphids provide valuable ecosystem services such as pollination, pest control or organic matter decomposition. In many cases, adults exploit pollen resources from the landscape to complete their life cycles. Yet, the knowledge about the most suitable plants for enhancing syrphid populations is still insufficient for most habitats. Also syrphid distribution across the landscape is understudied. In this work we analyzed: (i) syrphids distribution across different land uses and seasons in a Mediterranean landscape dominated by olive orchards, (ii) pollen resources exploited by the most abundant syrphid species and (iii) specific pollen resources relevant for egg production. Syrphids were captured weekly in spring, summer and autumn from April to November 2013 with a sweep net in patches with different land uses (olive orchards, herbaceous and scrubland patches). Nine species, generally with predatory aphidophagous larvae, were identified. The most abundant species was Sphaerophoria scripta (L.) followed by Melanostoma mellinum (L.). Sphaerophoria scripta was associated to olive orchards while M. mellinum was associated to herbaceous/scrubland patches. Pollen selection and consumption and number of eggs within gravid females for the most abundant species were determined through gut dissection and identified with a microscope. Several pollen types were showed a positive selection index by syrphid species. During spring and summer, the most ingested pollen types belonged to abundant plants in the patches of capture indicating that syrphids possibly do not need to fly among patches to feed during those periods. In spring, Asteraceae and Plantago type were particularly consumed by $S$. scripta and M. mellinum gravid females respectively while in summer feeding habits of males, gravid and non-gravid females did not differ. Females consumed more pollen than males but the number of eggs in gravid females was not related with the amount of ingested pollen grains. This study brings some insights about the seasonal variation of pollen feeding habits shown by adult syrphids across a Mediterranean heterogeneous landscape dominated by the olive orchard. In spring, dense flowering strips maintained within the olive orchards might attract and nourish adult syrphids while in summer syrphids might fly to non-crop areas to feed.
\end{abstract}

\footnotetext{
* Corresponding author at: Centro de Investigação de Montanha (CIMO), Instituto Politécnico de Bragança, Campus Sta Apolónia, $5300-253$ Bragança, Portugal. E-mail address: jpereira@ipb.pt (J.A. Pereira).
} 


\section{Introduction}

Conservation of beneficial arthropods in agricultural landscapes can result in economic benefits due to the ecosystem services they provide (e.g. pollination, pest control, decomposition). Many beneficial arthropods exploit resources from flowering plants; such as pollen and nectar however, there is relatively insufficient information about the most suitable plants for providing resources for most beneficial arthropods, their distribution in the agricultural system and the landscape structure required to maintain beneficial species (e.g. Isaacs et al., 2009).

Among beneficial arthropods, syrphids (Syrphidae: Diptera) represent a relevant group of predators, decomposers and pollinators because: (i) larvae of many species prey on aphids and the early stages of moths and psyllids, acting as predators of pests (Van Veen, 2010; Speight, 2017; Schneider, 1969); (ii) larvae of some species are decomposers (Speight, 2017); and (iii) adults of many species use flower resources, feeding on pollen and nectar (Jauker and Wolters, 2008; Schneider, 1969), acting as pollinators (Inouye, 2018; Nye and Anderson, 1974). Females and males of some syrphid species show different feeding habits. Adult females need pollen for egg development and consume higher amounts of pollen. Males consume more nectar, used for mate seeking, tissue maintenance and spermatogenesis (Haslett, 1989a; Hickman et al., 1995; Irvin et al., 1999; Wratten et al., 1995). Additionally, different species vary in the level of specialization of flower resources (Klecka et al., 2018). The knowledge about the native flowering plants selected and consumed by syrphid is essential to enhance syrphids in a conservation biological control perspective and/or as providers of pollination or other ecosystem services.

The olive tree is one of the principal crops in Mediterranean climatic areas all over the world. Due to the predatory behavior syrphids potentially prey on the olive tree pests Prays oleae (Bern.) - Praydidae and Palpita vitrealis (Rossi) - Crambidae, and other psyllids (e.g. Euphyllura straminea Loginova) (Pinheiro et al., 2013), being known predators of Euphyllura olivina (Costa) - Psyllidae (Rojo et al., 1999). Furthermore, the presence of syrphids in agroecosystems contributes with pollination to various crops such as almonds (Klein et al., 2012) and natural biological control for other Mediterranean crop pests (e.g. in vineyard, almond, cereals or vegetable crops).

Selection and consumption of floral resources (nectar and pollen) may vary between seasons accordingly to the food availability and syrphid requirements. In olive orchards agroecosystems from the northeast of Portugal the autumn is characterized by floral scarcity when compared with the spring. A previous study showed that during autumn syrphid species fed on pollen from herbaceous and woody vegetation occurring in within crops and non-crop areas (Villa et al., 2016). Those results suggested that in autumn a heterogeneous landscape could benefit syrphids providing them with a variety of food resources. During spring food resources abound, the peak of plant blooming takes place and syrphids are primarily active, reproducing and acting as natural control agents (Schneider, 1969; Speight, 2017). However, in Mediterranean areas, their feeding habits during this period are understudied.

Pollen of plants have particular characteristics which make it useful for a variety of studies in different fields such as taxonomy, evolution, climate change or arthropod behavior. Those characteristic include: (i) the presence of a tough outer coat (the exine); and (ii) the form and sculpture of the exine varies among pollen groups (pollen types). The exine remains after acid digestion, and its particular form and sculpture allows the identification of pollen types that correspond to family, genus, species or a group of several taxa (Moore et al., 1991).

Syrphid species mostly digest pollen grains through enzymes in the midgut. Afterward, the pollen exine remains visible (Gilbert, 1981; Haslett, 1983), this allows identifying ingested pollen types through gut dissection and microscope. Thus, different authors analyzed pollen within guts and verified pollen consumption as well as determined seasonal and gender-specific feeding patterns (Hickman et al., 1995;
Irvin et al., 1999; Wratten et al., 1995; Haslett, 1989a, 1989b; Villa et al., 2016).

In this context, in order to determine the most suitable non-crop plants for enhancing syrphids in agricultural Mediterranean areas, we aimed at: (i) identifying the most abundant syrphid species in olive tree crop and non-crop habitats (olive orchards, herbaceous patches and scrubland patches) from spring to autumn; (ii) analyzing their potential food resources; (iii) analyzing native pollen selection and consumption by abundant syrphids across different land uses and seasons through gut dissection and posterior pollen identification; (iv) determining the relationship between the amount and community of pollen consumed and the number of eggs produced by gravid females.

\section{Material and methods}

\subsection{Study areas}

The studied area was located in Mirandela municipality, northeast of Portugal Three olive orchards (Orchard 1: $41^{\circ} 29^{\prime} 16^{\prime \prime} \mathrm{N},-7^{\circ} 07^{\prime} 34^{\prime \prime} \mathrm{W}$, Orchard 2: $41^{\circ} 32^{\prime} 08^{\prime \prime} \mathrm{N},-7^{\circ} 07^{\prime} 29^{\prime \prime} \mathrm{W}$, and Orchard 3: $41^{\circ} 34^{\prime} 12^{\prime \prime} \mathrm{N}$, $-7^{\circ} 09^{\prime} 59^{\prime \prime} \mathrm{W}$ ), were selected. And for each orchard two adjacent noncrop fields, one with herbaceous area and another one scrubland were chosen, in a total of nine sampling areas (see Villa et al., 2016). The distance between olive orchards was 5 to $9 \mathrm{~km}$ and the non-crop areas in each olive orchard were far 100 to $600 \mathrm{~m}$. No pesticides were applied and no tilling was accomplished during the experimental period.

\subsection{Syrphids}

In order to capture syrphid species, weekly samplings were carried out from April (week 17) to November (week 46) 2013 with a sweep net, once it is considered an effective method (Ricarte and Marcos García, 2008). In each area sweeping was performed in all plant strata randomly during $30 \mathrm{~min}$. Samples were transported to the laboratory in a portable fridge. In the laboratory, collected specimens were frozen $\left(-18^{\circ} \mathrm{C}\right)$ and further identified according to Van Veen (2010) until dissection during the following months.

\subsection{Pollen analyses}

Each syrphid was dissected following the procedure described in Villa et al., (2016). Then, the gut content was diluted in a glycerin: water solution (1:1) in a microcentrifuge tube $(1.5 \mathrm{ml})$ to allow the counting and identification of the large amount of pollen ingested by syrphids. The solution volume was $1 \mathrm{ml}$ for females due to their larger consumption of pollen, and $0.5 \mathrm{ml}$ for males. Subsequently, solutions were mixed on a vortex, $65 \mu \mathrm{l}$ were transferred onto a glass slide and a coverslip $(22 \times 22 \mathrm{~mm})$ was applied. Pollen grains were counted and identified to pollen type employing a microscope. One pollen type can include one or several taxonomic groups, depending on the taxonomic discrimination achievable. Identification was based on Valdés et al. (1987) and Moore et al. (1991) and supported by a reference pollen collection hosted at the School of Agriculture, Polytechnic Institute of Bragança. When there were more than 5000 pollen grains, half of the slide was counted, and when there were more than 15,000, a quarter of the slide was counted; the total number of grains was estimated thereafter accordingly to the previous dilution. Additionally, the number of eggs from gravid females was recorded.

\subsection{Availability of pollen in the environment}

For availability of pollen in the environment, flowering plant inventories were carried out in each patch simultaneously with the syrphid collection: five flowering plant inventories were carried out in circular plots of $25 \mathrm{~m}^{2}$ (olive orchards and herbaceous patches) and three in circular plots of $100 \mathrm{~m}^{2}$ (scrubland patches). The percentage 
ground cover for each flowering plant species was recorded following the Dubenmire cover scale modified by Baley (Mueller-Dombois and Ellanberg, 1974). Plant species were grouped by pollen type for further analysis. Grouping was based on similarities related to the morphology of the pollen grains: family, genus, species or type (grouping several species or genus). The flowering plant inventories used are published in Villa et al. (2019) and Villa et al. (2016).

\subsection{Data analyses}

\subsubsection{Association between the most abundant syrphids species and the patch type}

The association between the most abundant syrphid species and the patch type (olive orchard, herbaceous or scrubland) was analyzed using a contingency table (calculated in Excel). The most abundant syrphids species (with species as levels) and the patch type (with type of land use as levels) were the categorical variables and a chi-square $\left(\chi^{2}\right)$ test was applied to analyze the relationship among them.

\subsubsection{Pollen selection and consumption}

Jacobs's second selection index $\left(D_{i}\right)$ was used to compare the consumption frequency of a species to its availability. A positive Jacobs's index value indicates selection of the resource and a negative avoidance. This index is defined as (Manly et al., 2002):

$D i=\frac{O_{i}-\widehat{\pi}_{i}}{O_{i}-\widehat{\pi}_{i}-2 O_{i} \widehat{\pi}_{i}}$

where $\mathrm{O} i$ is the proportion of used units (number of pollen grains) in the category $i$ (pollen type) calculated as $O i=U_{i} / U_{+}$, (Ui: number of consumed pollen grains of pollen type $i$ by an specimen; $U_{+}$: total number of consumed pollen grains by a specimen) and $\widehat{\pi}_{i}$ is the sample of the proportion of available units (percentage of ground covered) that are in pollen type $i$ calculated as $\widehat{\pi}_{i}=m_{i} / m_{+}$( $m_{i}$ : availability of pollen type $i$, previously estimated; $m_{+}$: percentage of ground covered by pollen, i.e., sum of the percentages of ground covered by all pollen types for each date).

Thus, $D_{i}$ was calculated for each specimen using the corresponding $\widehat{\pi}_{i}$ registered in the date of its capture. Then, the mean of $D_{i}$ and $O_{i}$ for both males and females captured during the spring, the summer and the autumn was calculated.

\subsubsection{Overall pollen community composition within guts and relevant pollen types}

Differences in overall pollen community composition within guts of males, gravid and non-gravid females was visualized using nonmetric multidimensional scaling (NMDS) (999 permutations) plots and the distance type which allowed the minimum stress and $\mathrm{k}$ (metaMDS function from "vegan" package in R) (R Core Team, 2019). Different plots were drawn for the most abundant species in each season. One permutational multivariate analysis of variance (PERMANOVA) was then performed for each species to corroborate the results of the NMDS (Benhadi-Marín et al., 2020) using gravid females, non-gravid females and males as the three levels for the dependent variable and pollen types in gut as explanatory variable. Afterwards, a pairwise comparison was accomplished (pairwise.adonis function from "devtools" package) (Martinez Arbizu, 2019; Wickham et al., 2019). The pollen types driving the differences between the pollen composition ingested by gravid females, non-gravid females and males were studied through a similarity percentage analysis (SIMPER) (simper function from "vegan" package).

\subsubsection{Importance of pollen for egg production}

A generalized linear model (GLM) with negative binomial distribution to account with overdispersion and the Log-link between the expected value of the response variable and the systematic part of the model was used to: (i) fit the amount of pollen in guts as a function of the factor leveled by gravid females, non-gravid females and males, and (ii) fit the number of eggs in gravid females as a function of the amount of pollen in their guts ( $g l m . n b$ function from the "MASS “ package). Then, a Tukey test for post-hoc analysis was carried out in order to detect differences between levels using emmeans function from the "emmeans" package (Lenth, 2020).

\section{Results}

\subsection{Syrphid diversity from spring to autumn}

A total of 435 syrphids (Syrphidae: Diptera) were captured from April 2013 to November 2013. Syrphids were more abundant and richer in spring (from April to June 21) (313 specimens, 9 species), followed by summer (from June 21 to September 22) (78 specimens, 5 species) and autumn (from September 22 to November) (44 specimens, 4 species). The most abundant species during spring and summer was Sphaerophoria scripta (Linnaeus 1758) followed by Melanostoma mellinum (Linnaeus 1758). In autumn the most abundant species was Episyrphus balteatus (De Geer 1776) followed by M. mellinum. Few specimens of Melanostoma scalare (Fabricius 1794), Eupeodes corollae (Fabricius 1794) Eupeodes sp., Eristalis tenax (Linnaeus 1758), Eristalis sp. and Platycheirus sp. were also captured, most of them in May (the richest month). Most species presented predatory larvae and pollinator adults. Few individuals with saprophytic larva were captured (Table 1).

\subsection{Syrphid distribution across land uses and seasons}

During the spring, captures were higher in olive orchards and in herbaceous patches than in scrubland patches. The contingency table was applied for the most abundant species, M. mellinum and S. scripta, and showed a significant association between both species and the patch type $\left(\chi^{2}=11.925 ; p<0.05 ; \mathrm{df}=1\right)$. In particular, $M$. mellinum was positively associated with herbaceous and scrubland patches and $S$. scripta with olive orchards. From August to December, syrphids were captured only in the herbaceous patches.

\subsection{Native available pollen sources across seasons}

During the spring, $92 \%$ of the soil was covered by flowering plants grouped in 55 pollen types, being Asteraceae (42.61\%), Poaceae (14.20\%), Fabaceae undiff. (5.92\%), Cistaceae (2.96\%), Rumex type (2.90\%), Echium type (2.74\%) and Brassicaceae (2.72\%) the most abundant (Table A1, Appendix A).

During the summer, $10 \%$ of the soil was covered by flowering plants grouped in 35 pollen types. The most abundant were Asteraceae (7.02\%), Apiaceae (0.80\%), Fabaceae undiff. (0.62\%) and Daphne gnidium type $(0.47 \%)$ (Table A1, Appendix A).

During the autumn, $4 \%$ of the soil was covered by flowering plants grouped in 23 pollen types, being Asteraceae (2.02\%), Arbutus unedo (0.94\%), Brassicaceae $(0.24 \%)$ and Daphne gnidium type $(0.18 \%)$ the most abundant (Table A1, Appendix A).

\subsection{Pollen selection and consumption}

Pollen selection and consumption was analyzed for the most abundant species, i.e. S. scripta (both sexes during spring and females during summer) and $M$. mellinum (both sexes during spring).

\subsubsection{Sphaerophoria scripta}

Sphaerophoria scripta female specimens analyzed during the spring ( $\mathrm{n}=88$ ), $4.50 \%$ had no pollen grains in the gut and $95.50 \%$ consumed 23 pollen types. The ten most consumed pollen types (in \%) belonged to Asteraceae types (90.91\%) followed by Anthemis type (76.14\%), Cichorioideae pollen grains (65.91\%), Rumex type (34.09\%), Brassicaceae pollen grains (18.18\%), Caryophyllaceae pollen grains (18.18\%), 
Table 1

Abundance and richness of species found in olive orchards (Oliv), herbaceous vegetation patches (Herb) and Scrublands patches (Scrub) during spring, summer and autumn 2013. The functional group (FG) is indicated (Pr: Predatory larva, P: Pollinator adult; Sp: Saprophytic larva). Number of females and males are shown between brackets as followed: (number of females, number of males).

\begin{tabular}{|c|c|c|c|c|c|c|c|c|c|c|c|c|c|c|}
\hline \multirow[t]{2}{*}{ Syrphid species } & \multirow[t]{2}{*}{ FG } & \multicolumn{4}{|l|}{ Spring } & \multicolumn{4}{|c|}{ Summer } & \multicolumn{4}{|c|}{ Autumn } & \multirow[t]{2}{*}{ Total } \\
\hline & & Oliv & Herb & Scrub & Total & Oliv & Herb & Scrub & Total & Oliv & Herb & Scrub & Total & \\
\hline $\begin{array}{l}\text { Episyrphus balteatus (De Geer } \\
\text { 1776) }\end{array}$ & $\begin{array}{l}\mathrm{Pr} / \\
\mathrm{P}\end{array}$ & $\begin{array}{l}1 \\
(1,0)\end{array}$ & $\begin{array}{l}2 \\
(1,1)\end{array}$ & $\begin{array}{l}2 \\
(0,2)\end{array}$ & $\begin{array}{l}5 \\
(2,3)\end{array}$ & 0 & $\begin{array}{l}1 \\
(1,0)\end{array}$ & 0 & $\begin{array}{l}1 \\
(1,0)\end{array}$ & 0 & $\begin{array}{l}18 \\
(8,10)\end{array}$ & 0 & $\begin{array}{l}18 \\
(8,10)\end{array}$ & $\begin{array}{l}24 \\
(11,13)\end{array}$ \\
\hline Eristalis tenax (Linnaeus 1758) & Sp & $\begin{array}{l}1 \\
(1,0)\end{array}$ & 0 & 0 & $\begin{array}{l}1 \\
(1,0)\end{array}$ & 0 & 0 & 0 & 0 & 0 & 0 & 0 & 0 & $\begin{array}{l}1 \\
(1,0)\end{array}$ \\
\hline Eristalis sp & Sp & 0 & $\begin{array}{l}2 \\
(0,2)\end{array}$ & 0 & $\begin{array}{l}2 \\
(0,2)\end{array}$ & 0 & 0 & 0 & 0 & 0 & 0 & 0 & 0 & $\begin{array}{l}2 \\
(0,2)\end{array}$ \\
\hline $\begin{array}{l}\text { Eupeodes corollae (Fabricius } \\
\text { 1794) }\end{array}$ & $\begin{array}{l}\mathrm{Pr} / \\
\mathrm{P}\end{array}$ & $\begin{array}{l}3 \\
(3,0)\end{array}$ & $\begin{array}{l}1 \\
(0,1)\end{array}$ & $\begin{array}{l}1 \\
(1,0)\end{array}$ & $\begin{array}{l}5 \\
(4,1)\end{array}$ & 0 & $\begin{array}{l}1 \\
(1,0)\end{array}$ & 0 & $\begin{array}{l}1 \\
(1,0)\end{array}$ & 0 & 0 & 0 & 0 & $\begin{array}{l}6 \\
(5,1)\end{array}$ \\
\hline Eupeodes sp & $\begin{array}{l}\mathrm{Pr} / \\
\mathrm{P}\end{array}$ & 0 & $\begin{array}{l}1 \\
(0,1)\end{array}$ & 0 & $\begin{array}{l}1 \\
(0,1)\end{array}$ & 0 & 0 & 0 & 0 & 0 & 0 & 0 & 0 & $\begin{array}{l}1 \\
(0,1)\end{array}$ \\
\hline $\begin{array}{l}\text { Melanostoma mellinum } \\
\quad \text { (Linnaeus 1758) }\end{array}$ & $\begin{array}{l}\mathrm{Pr} / \\
\mathrm{P}\end{array}$ & $\begin{array}{l}31 \\
(19, \\
12)\end{array}$ & $\begin{array}{l}47 \\
(38,9)\end{array}$ & $\begin{array}{l}11 \\
(7,4)\end{array}$ & $\begin{array}{l}89 \\
(64,31)\end{array}$ & 0 & $\begin{array}{l}11 \\
(7,4)\end{array}$ & 0 & $\begin{array}{l}11 \\
(7,4)\end{array}$ & 0 & $\begin{array}{l}6 \\
(1,5)\end{array}$ & 0 & $\begin{array}{l}6 \\
(1,5)\end{array}$ & $\begin{array}{l}106 \\
(72,34)\end{array}$ \\
\hline $\begin{array}{l}\text { Melanostoma scalare (Fabricius } \\
\text { 1794) }\end{array}$ & $\begin{array}{l}\mathrm{Pr} / \\
\mathrm{P}\end{array}$ & $\begin{array}{l}1 \\
(0,1)\end{array}$ & 0 & 0 & $\begin{array}{l}1 \\
(0,1)\end{array}$ & 0 & $\begin{array}{l}2 \\
(2,0)\end{array}$ & 0 & $\begin{array}{l}2 \\
(2,0)\end{array}$ & 0 & $\begin{array}{l}10 \\
(10,0)\end{array}$ & 0 & $\begin{array}{l}10 \\
(10,0)\end{array}$ & $\begin{array}{l}13 \\
(12,1)\end{array}$ \\
\hline Platycheirus sp & $\begin{array}{l}\mathrm{Pr} / \\
\mathrm{P}\end{array}$ & 0 & $\begin{array}{l}1 \\
(0,1)\end{array}$ & 0 & $\begin{array}{l}1 \\
(0,1)\end{array}$ & 0 & 0 & 0 & 0 & 0 & 0 & 0 & 0 & $\begin{array}{l}1 \\
(0,1)\end{array}$ \\
\hline $\begin{array}{l}\text { Sphaerophoria scripta (Linnaeus } \\
\text { 1758) }\end{array}$ & $\begin{array}{l}\mathrm{Pr} / \\
\mathrm{P}\end{array}$ & $\begin{array}{l}132 \\
(58, \\
74)\end{array}$ & $\begin{array}{l}58 \\
(20, \\
38)\end{array}$ & $\begin{array}{l}18 \\
(11,7)\end{array}$ & $\begin{array}{l}208 \\
(89, \\
119)\end{array}$ & $\begin{array}{l}5 \\
(1, \\
4)\end{array}$ & $\begin{array}{l}55 \\
(47,8)\end{array}$ & $\begin{array}{l}3 \\
(2,1)\end{array}$ & $\begin{array}{l}63 \\
(50, \\
13)\end{array}$ & 0 & $\begin{array}{l}10 \\
(4,6)\end{array}$ & 0 & $\begin{array}{l}10 \\
(4,6)\end{array}$ & $\begin{array}{l}281 \\
(143, \\
138)\end{array}$ \\
\hline Total & & $\begin{array}{l}169 \\
(82, \\
87)\end{array}$ & $\begin{array}{l}112 \\
(59 \\
53)\end{array}$ & $\begin{array}{l}32 \\
(19 \\
13)\end{array}$ & $\begin{array}{l}313 \\
(160 \\
153)\end{array}$ & $\begin{array}{l}5 \\
(1, \\
4)\end{array}$ & $\begin{array}{l}70 \\
(58, \\
12)\end{array}$ & $\begin{array}{l}3 \\
(2,1)\end{array}$ & $\begin{array}{l}78 \\
(61, \\
17)\end{array}$ & 0 & $\begin{array}{l}44 \\
(23, \\
21)\end{array}$ & 0 & $\begin{array}{l}44 \\
(23, \\
21)\end{array}$ & $\begin{array}{l}435 \\
(244, \\
191)\end{array}$ \\
\hline Richness & & 6 & 7 & 4 & & 1 & 5 & 1 & & 0 & 4 & 0 & & 9 \\
\hline
\end{tabular}
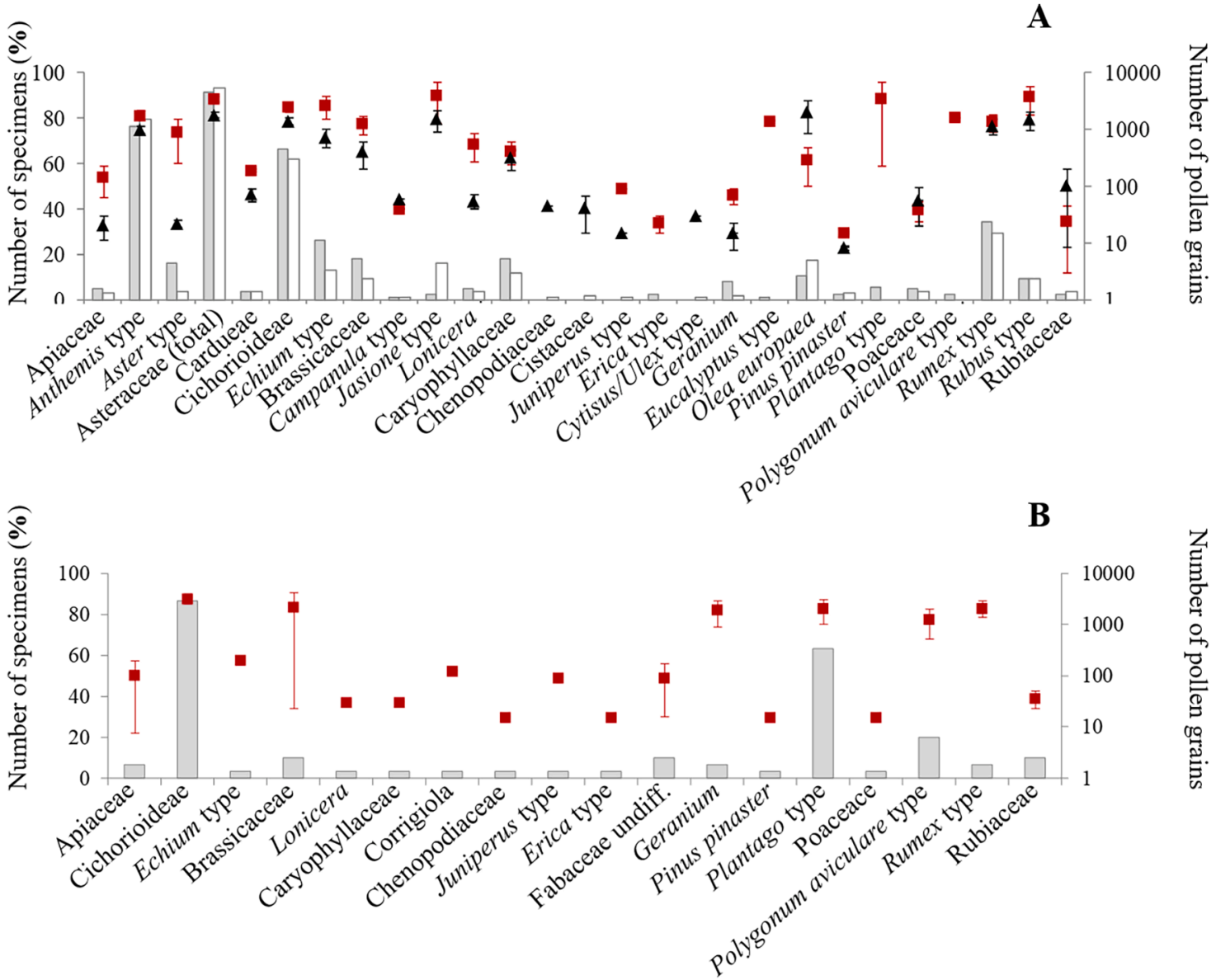

Fig. 1. Number of Sphaerophoria scripta specimens (\%) with the occurrence of each pollen type (females white bars and males grey bars) in the gut and the number of pollen grains (mean + standard error of the mean (SE)) counted within female ( $\square$ ) and male ( $\mathbf{A}$ ) guts in 2013 (A - Spring; B - Summer). A total of 89 females and 119 males were analyzed in spring and 50 females in summer. 
Aster type (15.91\%), Olea europaea pollen grains (10.23\%), Rubus type (9.09\%) and Geranium pollen grains (7.95\%) (see Fig. 1 - A for mean number of pollen grains \pm SE and other consumed pollen types). The selection index was positive for the consumption of Asteraceae types (D $=0.12$ ), Erica type, Eucalyptus type and Polygonum aviculare type (D = 1.00). Those three types were consumed by few individuals and did not occur in the inventoried patches (Table A1, Appendix A).

Sphaerophoria scripta male specimens analyzed during the spring (n $=110$ ), $3.60 \%$ had no pollen grains in the gut and $96.40 \%$ consumed 23 pollen types. The ten most consumed pollen types belonged to Asteraceae types (92.73\%), followed by Anthemis type (79.09\%), Cichorioideae pollen grains (61.82\%), Rumex type (29.09\%), Echium type (12.73\%), Caryophyllaceae pollen grains (11.82\%) and Rubus type (9.09\%) (see Fig. 1 - A for mean number of pollen grains \pm SE and other consumed pollen types). The selection index was positive for the consumption of Asteraceae pollen grains ( $\mathrm{D}=0.22)$, for Anthemis type ( $\mathrm{D}=$ 0.03), for Chenopodiaceae and for Juniperus type (both with $\mathrm{D}=1.00$ and not present in the inventoried patches) (Table A1, Appendix A).

During spring, some relatively abundant types such as Poaceae (14.20\%), Fabaceae undiff. (5.92\%), Cistaceae (2.96\%), Lavandula type (2.92\%), Cytisus/Ulex type (2.33\%), Quercus type (2.25\%) were never or rarely consumed by $S$. scripta females and males during the spring (Table A1, Appendix A).

Sphaerophoria scripta female specimens analyzed during the summer ( $\mathrm{n}=30$ ), $10.00 \%$ had no pollen grains in the gut and $90.00 \%$ of the specimens consumed 19 pollen types. The six most consumed pollen types belonged to Cichorioideae pollen grains (86.67\%), followed by Plantago type (63.33\%), Polygonum aviculare type (20.00\%), Rubiaceae pollen grains $(10.00 \%)$, Fabaceae undiff $(10.00 \%)$ and Brassicaceae pollen grains (10.00\%) (see Fig. 1 - B for mean number of pollen grains $\pm \mathrm{SE}$ and other consumed pollen types). The index selection was positive for the consumption of Cichorioideae pollen grains $(\mathrm{D}=0.72)$ and Plantago type $(\mathrm{D}=0.18)$. Lonicera periclymenum type, Juniperus type, Erica type, Geranium, Pinus pinaster, Polygonum aviculare type, Rumex type and Rubiaceae had $\mathrm{D}=1.00$ and were not present in the inventoried patches (Table A1, Appendix A).

\subsubsection{Melanostoma mellinum}

Melanostoma mellinum female specimens analyzed during the spring ( $\mathrm{n}=53$ ), $7.50 \%$ had no pollen grains in the gut and $92.50 \%$ consumed 22 pollen types. The ten most consumed pollen types belonged to Plantago type (73.58\%), followed by Asteraceae types (37.74\%),
Cichorioideae (32.07\%), Poaceae (16.98\%), Rumex type (13.21\%), Brassicaceae (11.32\%), Anthemis type (11.32\%), Echium type (9.43\%), Rubus type (9.43\%) and Salix (7.55\%) (Fig. 2). The selection index was positive for Plantago type ( $\mathrm{D}=0.56)$. Juniperus type, Ericaceae undiff. and Polygonum aviculare type had $\mathrm{D}=1.00$; however, they were consumed by few individuals and were not present in the inventoried patches. The selection index was lower than -0.74 for all the other types (Table A1, Appendix A).

Melanostoma mellinum male specimens analyzed during the spring (n $=28$ ), $28.60 \%$ had no pollen grains in the gut and $71.40 \%$ of the specimens consumed 12 pollen types. The eight most consumed pollen types belonged to Asteraceae (32.14\%), followed by Cichorioideae (32.14\%), Plantago type (25.00\%), Poaceae pollen grains $(21.43 \%)$, Anthemis type (17.86\%), Juniperus type (10.71\%), Fabaceae undiff. pollen grains (10.71\%) and Echium type (7.14\%) (see Fig. 2 for mean number of pollen grains \pm SE and other consumed pollen types). The selection index was positive for the consumption of Juniperus type (D = 1.00 ) and was lower than -0.28 for all the other types.

During the spring, types such as Cistaceae (2.96\%), Lavandula type (2.92\%), Cytisus/Ulex type (2.33\%), Caryophyllaceae (2.28\%), Quercus type $(2.25 \%)$ or Olea europaea $(1.58 \%)$ were never or rarely consumed by $M$. mellinum females and males during that season. Also, Fabaceae undiff. (5.92\%) in the case of the females and Brassicaceae (2.72\%) and Rumex type $(11.32 \%)$ in the case of the males were rarely consumed (Table A1, Appendix A).

\subsection{Pollen community composition consumed by males, gravid and non- gravid females}

To ensure a sufficient sample size, the overall pollen community composition consumed by males, gravid and non-gravid females was analyzed for the most abundant species (i.e., $S$. scripa captured in spring and summer and $M$. mellinum captured in spring).

The NMDS showed that the pollen community composition found in the gut of $S$. scripta (Canberra distance, $\mathrm{k}=3$ ) and $M$. mellinum (bray distance, $\mathrm{k}=3$ ) were different for males, gravid and non-gravid females during spring, although for $S$. scripta (bray distance, $\mathrm{k}=3$ ) did not differ during summer (Fig. 3). This was corroborated by the PERMANOVA (S. scripta in spring: $\mathrm{F}=2.05$; d.f. $=2 ; \mathrm{P}=0.001 /$ S. scripta in summer: $\mathrm{F}$ $=1.40$; d.f. $=2 ; \mathrm{P}=0.074 / M$. mellinum in spring: $\mathrm{F}=5.3$; d.f. $=2 ; \mathrm{P}=$ 0.001). The pairwise comparison showed that differences in spring were due to the pollen consumed by gravid females of both $S$. scripta (gravid

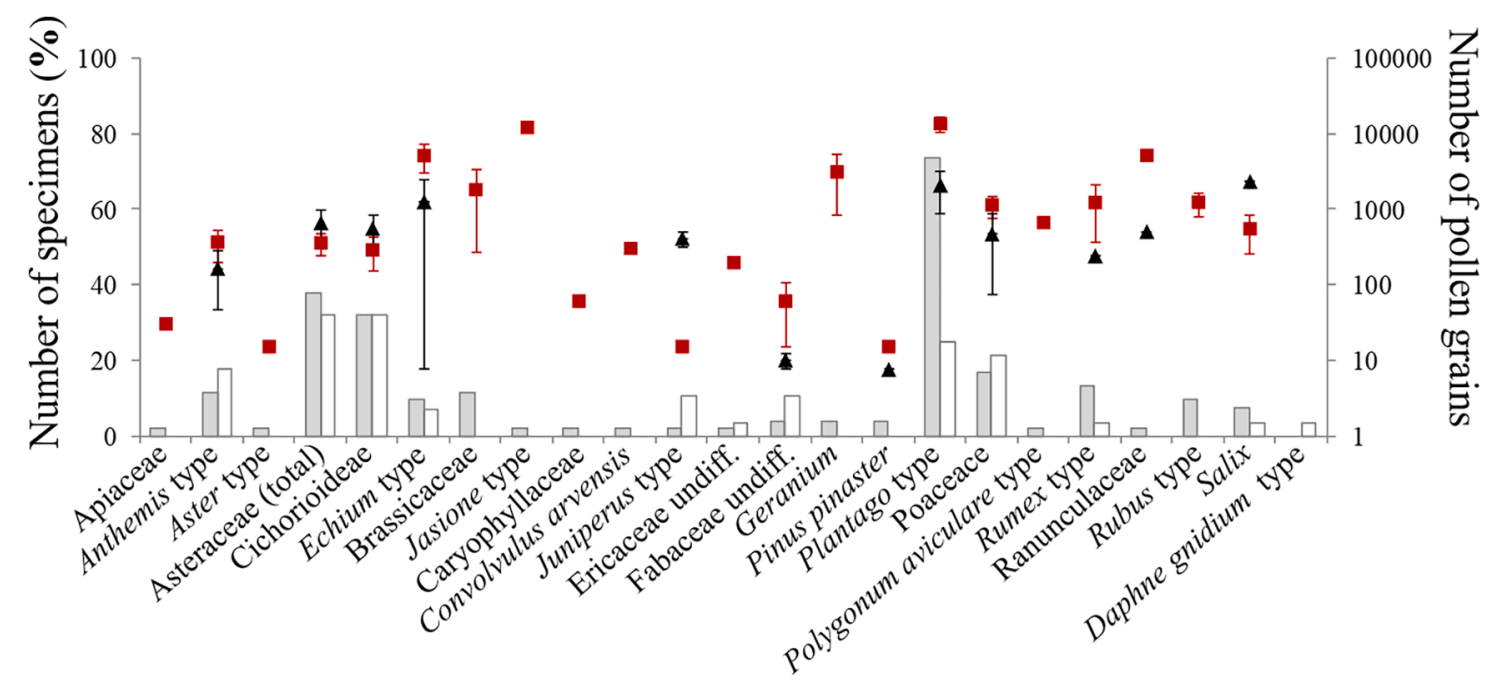

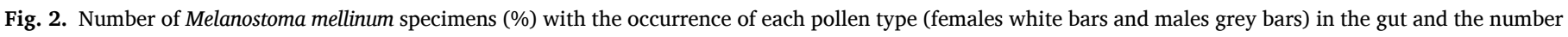

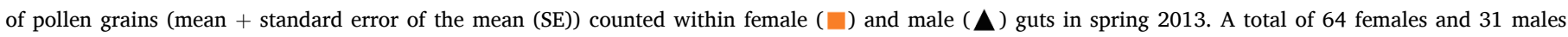
were analyzed. 

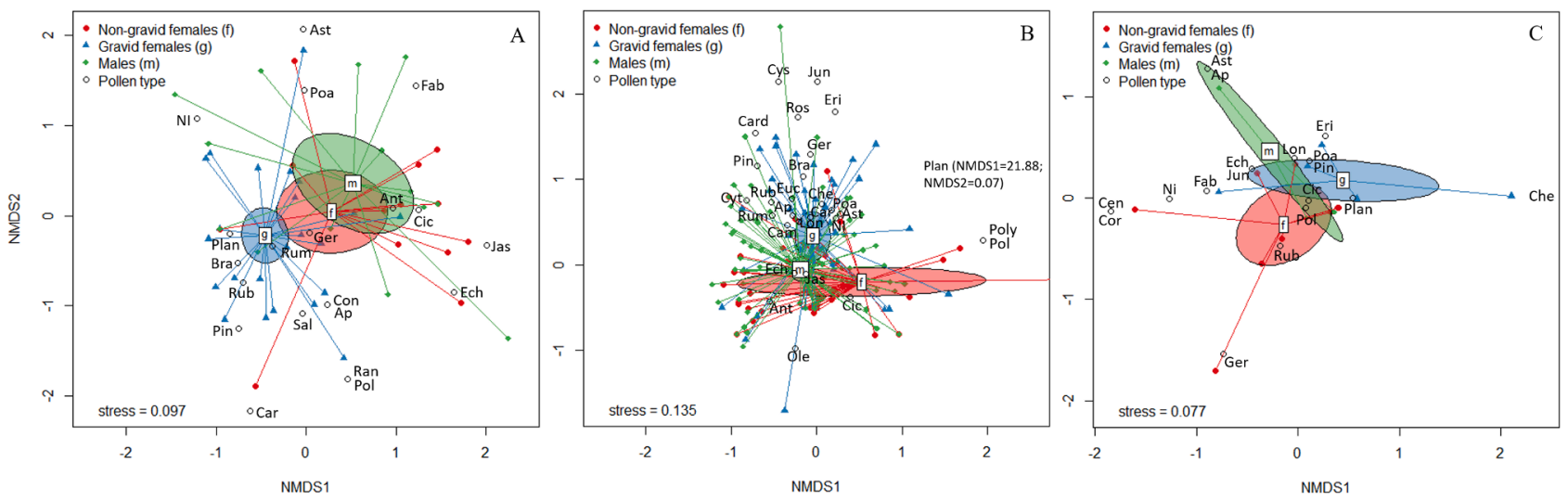

Fig. 3. Non-metric multidimensional scaling (NMDS) analysis for the pollen type species found in (o) the gut of syrphids collected during the 2013: non-gravid females ( $($ ), gravid females ( $\triangle$ ) and males ( $\diamond$ ) of spring Melanostoma mellinum (A), spring Sphaerophoria scripta (B) and summer S. scripta (C). Individuals connected to the centroid in each group ( $\mathrm{f}$ - non-gravid females; $\mathrm{g}$ - gravid females; $\mathrm{m}$ - males), and the $95 \%$ confident interval of each centroid is shown by shaded ellipses. Anthemis type (Ant); Apiaceae (Ap); Aster type (Ast); Brassicaceae (Bra); Campanula type (Cam); Cardueae (Card); Caryophyllaceae (Car); Centaurium (Cen); Chenopodium (Che); Cichorioideae (Cic); Convolvulus (Con); Corrigiola telephiifolia type (Cor); Cystus ladanifer (Cys); Echium type (Ech); Erica type (Eri); Eucalyptus type (Euc); Fabaceae (Fab); Geranium (Ger); Jasione type (Jas); Juniperus type (Jun); Lonicera (Lon); Not Identified (NI); Olea europaea (Ole); Pinus pinaster (Pin); Plantago (Plan); Poaceae (Poa); Polygonaceae (Pol); Polygonum (Poly); Ranunculaceae (Ran); Rosaceae (Ros); Rubus type (Rub); Rumex type (Rum); Salix (Sal).

vs non gravid females: $\mathrm{F}=2.32, \mathrm{P}=0.001$; gravid females vs males: $\mathrm{F}=$ $2.43, \mathrm{P}=0.001$; non gravid females vs males: $\mathrm{F}=1.51, \mathrm{P}=0.21$ ) and M. mellinum (gravid vs non gravid females: $\mathrm{F}=7.12, \mathrm{P}=0.001$; gravid females vs males: $\mathrm{F}=8.12, \mathrm{P}=0.001$; non gravid females vs males: $\mathrm{F}=$ $0.97, \mathrm{P}=0.49$ ).

In the case of $S$. scripta, SIMPER analysis showed that eight pollen types contributed for $90.94 \%$ of the differences found between the pollen community within guts of gravid and non-gravid females in spring: Cichorioideae (28.55\%), Anthemis type (26.29\%), Echium type (11.94\%), Rumex type (9.55\%), Brassicaceae (5.15\%), Rosaceae (4.38\%), Plantaginaceae (2.56\%), and Aster type (2.12\%), and eight pollen types contributed for $91.39 \%$ of the differences found between
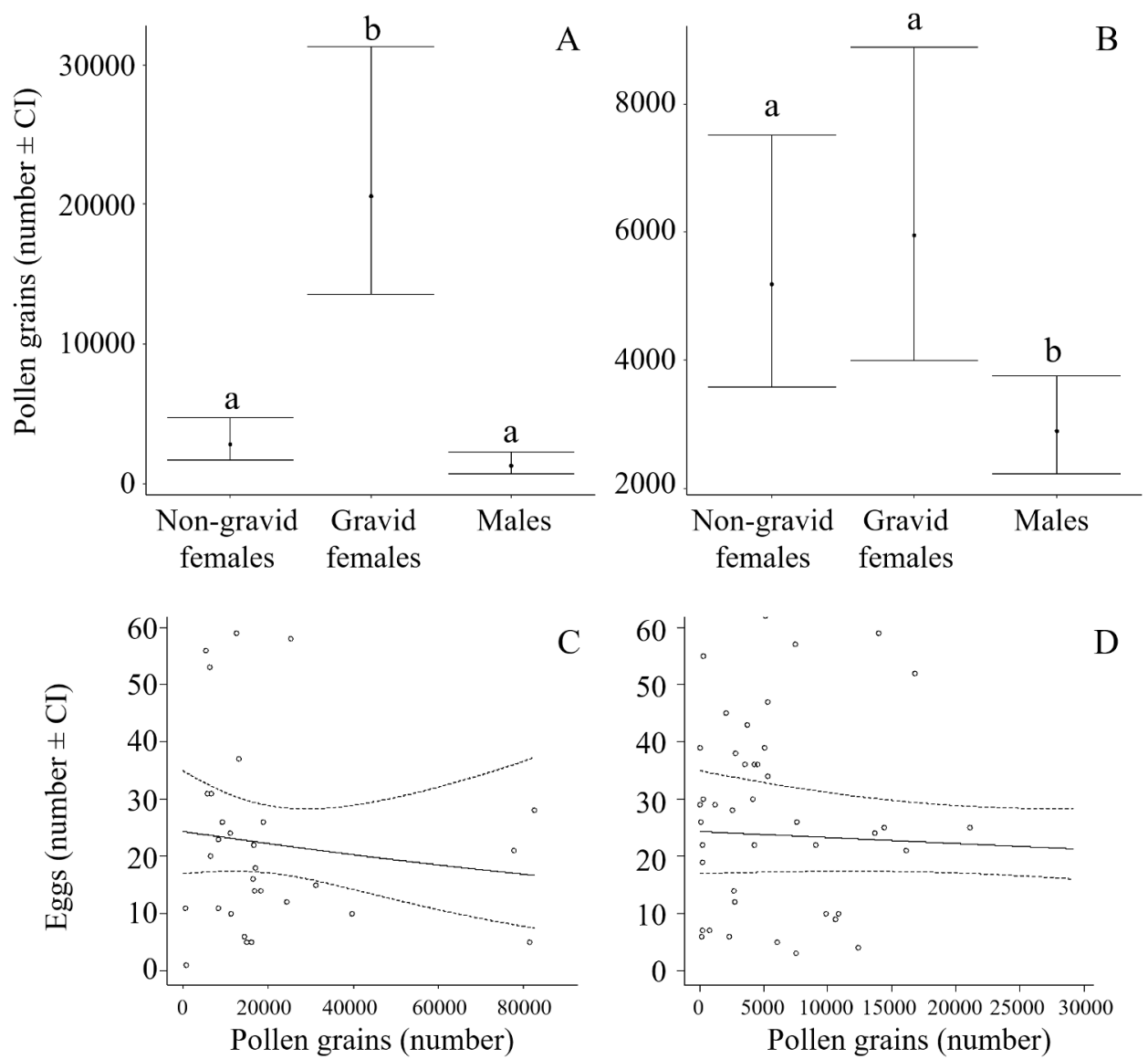

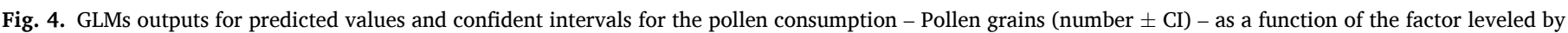

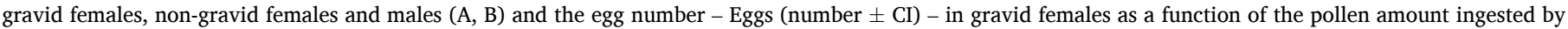
gravid females. Points represent observed values (C, D). The negative binomial distribution with the Log-link was used. 
gravid females and males: Anthemis type (26.96\%), Cichorioideae (22.91\%), Rumex type (12.21\%), Echium type (10.21\%), Brassicaceae (6.67\%), Rosaceae (5.51\%), Jasione type (3.44\%) and Olea europaea (3.38\%).

For M. mellinum in spring, SIMPER analysis showed that seven pollen types contributed for $90 \%$ of the differences found between the pollen community within guts of gravid and non-gravid females: Plantaginaceae $(66.86 \%)$, Not identified (6.46\%), Echium type (6.19\%), Poaceae (3.23\%), Jasione type (2.77\%), Brassicaceae (2.25\%) and Ranunculaceae $(2.24 \%)$, and six pollen types contributed for $90 \%$ of the differences found between gravid females and males: Plantaginaceae (69.18\%), Not identified (8.03\%), Echium type (4.82\%), Cichorioideae (2.71\%), Poaceae $(2.71 \%)$ and Anthemis type (2.55\%).

\subsection{Number of pollen grains consumed by males, gravid and non-gravid females}

The number of pollen grains occurring in the gut were counted in the same specimens referred in Section 3.5. The GLM showed that the pollen consumption was significantly higher in the case of $S$. scripta females (both gravid and non-gravid) when compared with males and in the case of $M$. mellinum gravid females when compared with both non-gravid females and males (Fig. 4 - A, B, Table A2).

\subsection{Relation between the number of eggs and the pollen consumed by gravid females}

Regarding $S$. scripta, from the 88 females analyzed during the spring, $48.86 \%$ presented a mean \pm SE of $33.98 \pm 3.87$ eggs and from the 33 analyzed during summer $42.42 \%$ presented a mean \pm SE of $30.50 \pm 3.91$ eggs. From the $53 \mathrm{M}$. mellinum females analyzed for egg production during the spring, $60.4 \%$ presented eggs with mean \pm SE of $22.125 \pm$ 2.885 eggs.

The relation between the number of eggs and the pollen consumed by gravid females was analyzed for the most abundant species (i.e. gravid females of $S$. scripta captured in spring and summer and of M. mellinum captured in spring). The GLM showed that the number of eggs in gravid females did not increase with the amount of pollen consumed (Fig. 4-C, D, Table A2).

\section{Discussion}

\subsection{Syrphid biodiversity and distribution across different land uses and seasons}

From the 195 syrphid species described for Portugal (Van Eck, 2016), nine species were found in the northeast of Portugal. Sphaerophoria scripta and $M$. mellinum were the most abundant, in agreement with other studies previously developed in the Mediterranean region (Ricarte and Marcos García, 2008; Ricarte et al., 2011). Syrphids occupy many different ecosystems (i.e. forests and woodlands, marshes, peatlands and bogs, damp grasslands, xerothermic grasslands, and gardens and residential areas) and each of these systems have its particular syrphid species (Van Veen, 2010). Open and anthropophilic habitats are typically preferred by S. scripta and M. mellinum (Speight, 2017). In this study, M. mellinum was associated with herbaceous and scrubland patches and $S$. scripta with olive orchards. Generally, all sampled sites were open areas (olive orchards and herbaceous patches) or with the occurrence of clearings in the case of the scrubland patches. In accordance, both species were previously found mostly in woodlands with the presence of clearings in Mediterranean areas (Ricarte et al., 2011).

Both species adults are active from the beginning of the spring to the middle of the autumn (Speight, 2017). In the northeast of Portugal, all the syrphid adult species presented peaks of abundance in the spring and decreased during the summer and the autumn, with the exception of S. scripta in herbaceous patches - which was female biased during the summer - and E. balteatus, which increased in the autumn.

\subsection{Seasonal and sex variations in pollen consumption by syrphids}

Pollen consumption by $S$. scripta varied with the season, i.e. while some pollen types were consumed in both the spring and the summer, others were consumed in the spring but rarely consumed in the summer or consumed in the summer but rarely in the spring. Additionally, pollen consumption by gravid females vs non-gravid or males only differed in the spring (for both $S$. scripta and M. mellinum), while no differences were found in the summer (only studied for $S$. scripta). In a previous study, the amount of pollen consumed by females and males of E. corollae and E. balteatus during the autumn did not differ, (Villa et al., 2016), similarly to the observed in the present study for the summer and differently from the spring. Seasonal differences in pollen consumption may be due to: (i) differences in nutritional requirements for gravid females during the spring for egg production (Haslett, 1989a; Hickman et al., 1995; Irvin et al., 1999; Wratten et al., 1995) and (ii) plants blooming period, which condition the pollen availability Thus our results indicate that:

(i) During the spring, females could need food resources for reproduction. That may be the reason why the gut content of gravid females differ from non-gravid females and males, while in the autumn probably they may only need energy for maintenance, resulting in similar gut content for all syrphids. These results are in agreement with several previous studies (Haslett, 1989a; Irvin et al., 1999). However, in this study the number of eggs was not related with the amount of pollen consumed by gravid females.

(ii) Both M. mellinum (in spring) and S. scripta (in spring and summer) mainly consumed pollen from occurring blooming plants in the patches where they were captured. Conversely, in autumn characterized by flowers scarcity in Mediterranean areas - Villa et al. (2016) results suggested that syrphids (E. corollae and E. balteatus) flew among patches to forage, collecting pollen from multiple habitats. Syrphid feeding behavior may shift between periods of food abundance (spring) and food scarcity (summer and autumn). In agreement, syrphids performed a sequential exploitation of pollen types in different landscape patches and at different periods of the year (Branquart and Hemptinne, 2000) and many beneficial insects spill over from semi-natural habitats, where they overwinter, to crop fields where they provide ecosystem services such as biological control and pollination (Vialatte et al., 2019, see references therein). Moreover, Moquet et al. (2018) suggested that syrphids were attracted by dense patches of flowers. Thus, during spring, syrphid may feed on available dense patches of flowers while in autumn may fly among patches to search scarce flower resources. From a management perspective, flowering patches, strips or ground covers within the crop may be important as food resource for syrphids during spring and the landscape heterogeneity during autumn. Previous studies indicated that mosaic patches/vegetation types are necessary for syrphids to complete their life cycles (Ricarte et al., 2011; Haslett, 1997). In accordance, Kleijn and van Langevelde (2006) found natural areas to have a positive effect on syrphid richness only when flower abundance was relatively high.

\subsection{Relevant pollen types for S. scripta and M. mellinum}

Pollen selection and consumption was analyzed for species with sufficient captures, i.e. for S. scripta in spring and summer and M. mellinum in spring.

Several plant species resulted in a positive Jacobs's index selection $\left(D_{i}\right)$ and/or a high proportion of consumed pollen grains $\left(O_{i}\right)$. A positive $D_{i}$ could mean that syrphids (i) have actively searched for flowers or (ii) 
licked the pollen from vegetation surfaces. A negative $D_{i}$ could indicate that: (i) the plant species is unattractive; (ii) a low percentage of ground cover by that plant (low $\pi_{i}$ ) could make it undetectable; (iii) the flower pollen is inaccessible for the insects or (iv) the high percentage of ground covered by that plant (high $\pi_{i}$ ) exceed the adult needs (Villa et al., 2019).

Several plant families were described as a common food resource for S. scripta (white Apiaceae, Asteraceae, Campanulaceae, Euphorbiaceae, Lamiaceae, Papaveraceae, Ranunculaceae, Rosaceae) and M. mellinum (white Apiaceae, Amaryllidaceae, Asteraceae, Caprifoliaceae, Caryophyllaceae, Euphorbiaceae, Juncaceae, Papaveraceae, Plantaginaceae, Ranunculaceae, Salicaceae, Poaceae) (Speight, 2017).

In the northeast of Portugal some of those pollen types were also consumed by $S$. scripta (e.g., Asteraceae or Rosaceae) and M. mellinum (e. g. Plantago type, Asteraceae and Poaceae). Furthermore, they consumed other pollen types: Rumex type, Caryophyllaceae, Olea europaea, Geranium sp. (Geraniaceae), Caryophyllaceae or Rubiaceae in the case of S. scripta and Rumex type and Polygonum aviculare type (Polygonaceae), Brassicaceae, Echium type (Boraginaceae) or Rubus type (Rosaceae) in the case of M. mellinum. Asteraceae (for S. scripta) and Plantago type (for M. mellinum) can be stand out because they were highly consumed by gravid females. In agreement, Hickman et al. (1995) showed that Melanostoma fasciatum (Macquart) gravid females consumed large amount of specific pollen types (among them Plantago sp.).

Flower visibility and nectar/pollen accessibility are important traits for syrphids plant preference (Branquart and Hemptinne, 2000). Most of the plant families consumed in this study had accessible pollen (e.g. Asteraceae, Plantaginaceae). Deep and narrow flowers can be accessed by the proboscis of $S$. scripta, which may exploit nectar in a wider diversity of corolla shapes (Branquart and Hemptinne, 2000) such as Echium type in this study (showing a certain degree of importance for gravid females of both species). Other plants producing small amounts of nectar or even no nectar producers can be very attractive if occurring in large patches and having numerous stamens (Branquart and Hemptinne, 2000). In the studied area, Brassicaceae occurs in extensive patches of flowers (personal observation) and commonly Brassicaceae species showed positive effects as insectary plants for syrphids (BadenesPérez, 2019). However, in this study Brassicaceae were not highly consumed.

Some available plants (in some cases, relatively abundant) and commonly visited by M. mellinum (e.g., Caryophyllaceae) or S. scripta (e. g., Apiaceae) in other studies (Colley and Luna, 2000; Speight, 2017; Martínez-Uña et al., 2013; Wojciechowicz-Żytko, 2019) were rarely or not consumed. This could be due to several reasons: (i) syrphids may visit flowering plants for nectar but not for pollen, making visitation undetectable using gut pollen analyses; (ii) interspecific competition avoidance (Ambrosino et al., 2006); (iii) occurrence of more attractive species (Colley and Luna, 2000); (iv) phenotypic interregional variations among populations; ( $v$ ) disperse distribution of the plant specimens instead of dense patches of flowers; (vi) desynchronization between the plant blooming and the flight period in the area.

Similar to Chrysoperla carnea s.l (Stephens) in the northeast of Portugal (Villa et al., 2019), some of the most consumed pollen grains belonged to anemophilous pollen types, e.g. Plantago type (Plantaginaceae) and Poaceae by $M$. mellinum females and males; Rumex type (Polygonaceae) and Salix (Salicaceae) by M. mellinum females; Juniperus type (Cupressaceae) by M. mellinum males; Rumex type and Olea europaea (Oleaeceae) by $S$. scripta females. Syrphids were previously found visiting anemophilous speciesm, e.g. Betulaceae, Cyperaceae, Fagaceae, Plantaginaceae, Poaceae, Polygonaceae, Salicaceae (see Saunders, 2018) and particularly, Melasnostoma spp. was found visiting anemophilous plants (see Inouye et al., 2015). Natural enemies and pollinators could benefit from wind-pollinated plants pollen because they tend to flower earlier than animal-pollinated species and may provide critical nutrients in temperate regions during the early spring before the floral resource peaks (Saunders, 2018).

\subsection{Implications for ecosystem services}

\subsubsection{Biological control}

Both S. scripta and M. mellinum feed on aphids including various crop plants, such as Avena, Brassica, Cichorium, Lactuca, Triticum and Vicia for S. scripta or Lactuca for M. mellinum (Speight, 2017). From a conservation biological control perspective, attraction of natural enemies to crops was responsible for a substantial reduction in local prey densities in theoretical models (Kean et al., 2003) and particularly the increase of syrphids, attracted to the crop by non-crop plants, were related with a decrease of the pest, i.e. the cabbage aphids Brevicoryne brassicae (L.), the green peach aphid, Myzus persicae (Sulzer), wheat aphids and psyllid pests (White et al., 1995; Hickman and Wratten, 1996; Jankowska and Wojciechowicz-Żytko, 2016). In the studied Mediterranean area, several crop plants such as cereal, vegetable crops or cherry trees are cultivated and these crops are attacked by aphids (van Emden and Harrington, 2017). The occurrence of syrphids in the area, which can find their food resources in olive orchards and surrounding non-crop areas, could benefit those crops through the biological control of aphid or psyllid pests. Among the identified species in this work only E. balteatus and $E$. corollae are referred as potential predators of the olive tree pests E. olivina and P. vitrealis respectively (Pinheiro et al., 2013). However, M. mellinum and S. scripta may also act as natural control agents of olive tree pests and, given its abundance in the area, this aspect is worthy of deeper research.

\subsubsection{Pollination}

Under the current decline in social bee populations, the importance of syrphids as pollinators arises (see Raguso, 2020). The increase of pollinators triggered by larger areas of uncultivated land has been positively related with a higher yield production (Morandin and Winston, 2006). In the northeast of Portugal, many crops could benefit from higher pollinator populations (Klein et al., 2007) (e.g. vegetables such as strawberry, pumpkin or cabbages and trees such as cherry, almond or chesnut) (Ssymank et al., 2009; Nye and Anderson, 1974). For example, Sphaerophoria spp. and Melanostoma spp. participate in the strawberry and cereals pollination respectively (Ssymank et al., 2009; Nye and Anderson, 1974) and E. balteatus significantly increased both seed set and yield of oil-seed rape (Brassica napus L.) (Jauker and Wolters, 2008).

\section{Conclusion}

In this experiment, relevant pollen sources (e.g., Asteraceae and Plantago type for gravid S. scripta and M. mellinum respectively) and its distribution across land uses (S. scripta associated to olive orchard and M. mellinum to herbaceous/scrubland patches) for syrphids in a Mediterranean landscape dominated by the olive orchard were identified. Non-crop areas with Plantago sp. or conservation of Asteraceae plant specimens within the crop may enhance $M$. mellinum and $S$. scripta respectively in Mediterranean areas dominated by olive orchards. Thus, the maintenance of areas with that non-crop species may promote syrphid mediated-ecosystem services such as predation and pollination in Mediterranean crops. Additionally, this study together with Villa et al. (2016) indicate that in periods with a high diversity of blooming plants (spring), syrphids possibly do not need to fly among patches with different land uses to feed. However, when the number of blooming plants decrease (summer and autumn) a heterogeneous landscape with herbaceous and woody vegetation surrounding the orchards may favor the syrphids. This suggests that possibly a comprehensive territorial planning, including local (herbaceous vegetation within the crop during spring) and landscape (heterogeneous landscape surrounding the crop) management practices, may contribute for conserving ecosystem services. Following Gagic et al. (2019), ecosystem services provide by syrphids should be quantified in order to measure the importance of syrphids for pest predation and crop pollination from an economical perspective and their potential additive and/or interactive effects on 
crop yields investigated, because agroecosystems are complex systems with multiple interactions (e.g. intraguild competition or predation) with may affect the final effect of different management strategies.

\section{Funding}

The authors are grateful to the Foundation for Science and Technology (FCT, Portugal) for financial support by national funds FCT/ MCTES to CIMO (UIDB/00690/2020), and project EXCL/AGR-PRO/ 0591/2012 "Olive crop protection in sustainable production under global climatic changes: linking ecological infrastructures to ecosystem functions." and M.V. Postdoc grant (SFRH/BPD/119487/2016).

\section{CRediT authorship contribution statement}

María Villa: Conceptualization, Methodology, Investigation, Writing - original draft, Writing - review \& editing. Sónia A.P. Santos: Conceptualization, Investigation, Writing - original draft, Writing - review \& editing. José Antonio López-Sáez: Methodology, Investigation, Funding acquisition. Lara Pinheiro: Methodology, Investigation. Rosalina Marrão: Methodology, Investigation. Carlos Aguiar: Methodology, Investigation. José Alberto Pereira: Conceptualization, Investigation, Writing - original draft, Writing - review \& editing.

\section{Appendix A. Supplementary data}

Supplementary data to this article can be found online at https://doi. org/10.1016/j.biocontrol.2021.104556.

\section{References}

Ambrosino, M.D., Luna, J.M., Jepson, P.C., Wratten, S.D., 2006. Relative frequencies of visits to selected insectary plants by predatory hoverflies (Diptera: Syrphidae), other beneficial insects, and herbivores. Environ. Entomol. 35 (2), 394-400. https://doi. org /10.1603/0046-225X-35.2.394.

Badenes-Pérez, F.R., 2019. Trap crops and insectary plants in the order brassicales. Ann. Entomol. Soc. Am. 112 (4), 318-329. https://doi.org/10.1093/aesa/say043.

Benhadi-Marín, J., Pereira, J.A., Sousa, J.P., Santos, S.A.P., 2019. Distribution of the spider community in the olive grove agroecosystem (Portugal): potential bioindicators. Agr. For. Entomol. 22 (1), 10-19. https://doi.org/10.1111/afe. v22.110.1111/afe.12352.

Branquart, E., Hemptinne, J.L., 2000. Selectivity in the exploitation of floral resources by hoverflies (Diptera: Syrphinae). Ecography 23, 732-742. https://doi.org/10.1111/ j.1600-0587.2000.tb00316.x.

Colley, M.R., Luna, J.M., 2000. Relative attractiveness of potential beneficial insectary plants to aphidophagous hoverflies (Diptera: Syrphidae). Environ. Entomol. 29 (5) 1054-1059. https://doi.org/10.1603/0046-225X-29.5.1054.

Gagic, V., Marcora, A., Howie, L., Diekötter, T., 2019. Additive and interactive effects of pollination and biological pest control on crop yield. J. Appl. Ecol. 56 (11) 2528-2535. https://doi.org/10.1111/jpe.v56.1110.1111/1365-2664.13482.

Gilbert, F.S., 1981. Foraging ecology of hoverflies: morphology of the mouthparts in relation to feeding on nectar and pollen in some common urban species. Ecol. Entomol. 6 (3), 245-262. https://doi.org/10.1111/j.1365-2311.1981.tb00612.x.

HASLETT, J.R., 1983. A photographic account of pollen digestion by adult hoverflies. Physiol. Entomol. 8 (2), 167-171. https://doi.org/10.1111/j.1365-3032.1983. tb00345.x.

Haslett, J.R., 1989a. Interpreting patterns of resource utilization: randomness and selectivity in pollen feeding by adult hoverflies. Oecologia 78 (4), 433-442. https:// doi.org/10.1007/BF00378732.

Haslett, J.R., 1989b. Adult feeding by holometabolous insects: pollen and nectar as complementary nutrient sources for Rhingia campestris (Diptera: Syrphidae). Oecologia 81 (3), 361-363. https://doi.org/10.1007/BF00377084.

Haslett, J.R., 1997. Insect communities and the spatial complexity of mountain habitats. Global Ecol. Biogeogr. 6, 49-56. https://doi.org/10.2307/2997526.

Hickman, J.M., Lövei, G.L., Wratten, S.D., 1995. Pollen feeding by adults of the hover fly Melanostoma fasciatum (Diptera: Syrphidae). N. Z. J. Zool. 22 (4), 387-392. https:// doi.org/10.1080/03014223.1995.9518057.

Hickman, J.M., Wratten, S.D., 1996. Use of Phelia tanacetifolia strips to enhance biological control of aphids by hoverfly larvae in cereal fields. J. Econ. Entomol. 8, 832-840. https://doi.org/10.1093/jee/89.4.832.

Inouye, D.W., 2018. Diptera as crop pollinators. In: Ward Roubik, D. (Ed.), The pollination of cultivated plants. A compendium for practitioners. Food and Agriculture Organization of the United Nations, pp. 31-37.

Inouye, D.W., Larson, B.M.H., Ssymank, A., Kevan, P.G., 2015. Flies and flowers III: ecology of foraging and pollination. J. Pollinat. Ecol. 16 (16), 115-133. https://doi. org $/ 10.26786 / 1920-7603 \% 282015 \% 2915$.
Irvin, N.A., Wratten, S.D., Frampton, C.M., Bowie, M.H., Evans, A.M., Moar, N.T., 1999. The phenology and pollen feeding of three hover fly (Diptera: Syrphidae) species in Canterbury, New Zealand. N. Z. J. Zool. 26 (2), 105-115. https://doi.org/10.1080/ 03014223.1999.9518182.

Isaacs, R., Tuell, J., Fiedler, A., Gardiner, M., Landis, D., 2009. Maximizing arthropodmediated ecosystem services in agricultural landscapes: the role of native plants. Front. Ecol. Environ. 7 (4), 196-203. https://doi.org/10.1890/080035.

Jankowska, B., Wojciechowicz-Żytko, E., 2016. Effect of intercropping carrot (Daucus carota L.) with two aromatic plants, coriander (Coriandrum sativum L.) and summer savory (Satureja hortensis L.), on the population density of select carrot pests. Folia Horticu. 28 (1), 13-18. https://doi.org/10.1515/fhort-2016-0002.

Jauker, F., Wolters, V., 2008. Hoverflies are efficient pollinators of oilseed rape. Oecologia 156, 819-823. https://doi.org/10.1007/s00442-008-1034-x.

Kean, J., Wratten, S., Tylianakis, J., Barlow, N., 2003. The population consequences of natural enemy enhancement, and implications for conservation biological control. Ecol. Lett. 6, 604-612. https://doi.org/10.1046/j.1461-0248.2003.00468.x.

Klecka, J., Hadrava, J., Biella, P., Akter, A., 2018. Flower visitation by hoverflies (Diptera: Syrphidae) in a temperate plant-pollinator network. PeerJ 6, e6025. https://doi.org/10.7287/peerj.preprints.26516v2.

Kleijn, D., van Langevelde, F., 2006. Interacting effects of landscape context and habitat quality on flower visiting insects in agricultural landscapes. Basic Appl. Ecol. 7 (3), 201-214. https://doi.org/10.1016/j.baae.2005.07.011.

Klein, A.M., Brittain, C., Hendrix, S.D., Thorp, R., Williams, N., Kremen, C., 2012. Wild pollination services to California almond rely on semi-natural habitat. J. Appl. Ecol. 49 (3), 723-732. https://doi.org/10.1111/j.1365-2664.2012.02144.x.

Klein, A.-M., Vaissière, B.E., Cane, J.H., Steffan-Dewenter, I., Cunningham, S.A., Kremen, C., Tscharntke, T., 2007. Importance of pollinators in changing landscapes for world crops. Proc. R. Soc. B. 274 (1608), 303-313. https://doi.org/10.1098/ rspb.2006.3721.

Lenth, R., 2020. emmeans: Estimated Marginal Means, aka Least-Sqares Means. R package version 1.4.4. <https://CRAN.R-project.org/package=emmeans $>$.

Manly, B.F.J., McDonald, L.L., Thomas, D.L., McDonald, T.L., Erickson, W.P., 2002. Resource Selection by Animals Statistical Design and Analysis for Field Studies, Second ed. Kluwer Academic Publishers, Dordrecht.

Martinez Arbizu, P., 2019. Pairwise Adonis: Pairwise multilevel comparison using adonis. $\mathrm{R}$ package version 0.3 .

Martínez-Uña, A., Martín, J.M., Fernández-Quintanilla, C., Dorado, J., 2013. Provisioning floral resources to attract Aphidophagous hoverflies (Diptera: Syrphidae) useful for pest management in central Spain. J. Econ. Entomol. 106 (6), 2327-2335. https://doi.org/10.1603/EC13180.

Morandin, L.A., Winston, M.L., 2006. Pollinators provide economic incentive to preserve natural land in agroecosystems. Agr. Ecosyst. Environ. 116 (3-4), 289-292. https:// doi.org/10.1016/j.agee.2006.02.012.

Moore, P.D., Webb, J.A., Collinson, M.E., 1991. Pollen Analysis. Blackwell Scientific Publications, Oxford.

Moquet, L., Laurent, E., Bacchetta, R., Jacquemart, A.-L., Didham, R., Gilbert, F., 2018. Conservation of hoverflies (Diptera, Syrphidae) requires complementary resources at the landscape and local scales. Insect Conserv. Diver. 11 (1), 72-87. https://doi.org/ 10.1111/icad.12245.

Mueller-Dombois, D., Ellanberg, H., 1974. In: Community Sampling: The Relevé Methods. Aims and Methods of Vegetation Ecology. John Wiley and Sons, USA, pp. $45-46$.

Nye, W.P., Anderson, J.L., 1974. Insect pollinators frequenting strawberry blossoms and the effect of honey bees on yield and fruit quality. J. Am. Soc. Hort. Sci. 99 (1), 40-44.

Pinheiro, L.A., Torres, L.M., Santos, S.A.P., 2013. In: Sirfídeos associados ao olival transmontano. Importância da vegetação herbácea espontânea na sua vitalidade. Instituto Politécnico de Bragança, p. 36.

R Core Team, 2019. R: A language and environment for statistical computing. $\mathrm{R}$ Foundation for Statistical Computing, Vienna, Austria. URL $<$ https://www.R-pro ject.org/>.

Raguso, R.A., 2020. Don't forget the flies: dipteran diversity and its consequences for floral ecology and evolution. Appl. Entomol. Zool. 55 (1), 1-7. https://doi.org/ 10.1007/s13355-020-00668-9.

Ricarte, A., Marcos García, M.A., 2008. Los sírfidos (Diptera: Syrphidae) del Parque Nacional de Cabañeros (España): una herramienta para la gestión. Boln. Asoc. esp. Ent. 32 (1-2), 19-32.

Ricarte, A., Ángeles Marcos-García, M., Moreno, C.E., 2011. Assessing the effects of vegetation type on hoverfly (Diptera: Syrphidae) diversity in a Mediterranean landscape: implications for conservation. J. Insect Conserv. 15 (6), 865-877. https:// doi.org/10.1007/s10841-011-9384-9.

Rojo, S., Pérez-Bañón, C., Marcos-Garcia, M.A., 1999. First observations on the biology of Scaeva mecogramma (Bigot, 1860) (Diptera, Syrphidae) and notes on some other syrphids preying on psyllids (Hemiptera, Aphalaridae and Triozidae). Volucella 4 105-111.

Saunders, M.E., 2018. Insect pollinators collect pollen from wind-pollinated plants: implications for pollination ecology and sustainable agriculture. Insect Conserv. Diver. 11 (1), 13-31. https://doi.org/10.1111/icad.12243.

Schneider, F., 1969. Bionomics and physiology of aphidophagous Syrphidae. Annu. Rev. Entomol. 14 (1), 103-124. https://doi.org/10.1146/annurev.en.14.010169.000535.

Speight, M.C.D., 2017. Species Accounts of the European Syrphidae (Diptera), Glasgow. In: Speight, M.C.D., Castella, E., Sarthou, J.P., Vanappelghem, C. (Eds.), Syrph the Net, the database of European Syrphidae, Dublin.

Ssymank, A., Hamm, A., Vischer-Leopold, M., 2009. Caring for pollinators safeguarding agro-biodiversity and wild plant diversity. Bundesamt für Naturschutz (BfN). Federal Agency for Nature Conservation. Bonn, Germany. 191 pp. 
Valdés, B., Diez, M.J., Fernandez, I., 1987. Atlas polínico de Andalucía occidental. Instituto de Desarrollo Regional. Universidad de Sevilla, Sevilla.

Van Eck, A., 2016. Hoverflies (Diptera, Syrphidae) new to the fauna of mainland Portugal, with an updated hoverfly checklist. Boletín de la S.E.A. 59, 187-203.

Van Emden, H.F., Harrington, R., 2017. Aphids as Crop Pests, second ed. CABI, Croydon, UK.

Van Veen, M.P., 2010. Hoverflies of Northwest Europe. Identification Keys to the Syrphidae. KNNV Publishing, Utrecht.

Vialatte, A., Barnaud, C., Blanco, J., Ouin, A., Choisis, J.-P., Andrieu, E., Sheeren, D., Ladet, S., Deconchat, M., Clément, F., Esquerré, D., Sirami, C., 2019. A conceptual framework for the governance of multiple ecosystem services in agricultural landscapes. Landscape Ecol. 34 (7), 1653-1673. https://doi.org/10.1007/s10980019-00829-4.

Villa, M., Santos, S.A.P., Marrão, R., Pinheiro, L.A., López-Saez, J.A., Mexia, A., Bento, A., Pereira, J.A., 2016. Syrphids feed on multiple patches in heterogeneous agricultural landscapes during the autumn season, a period of food scarcity. Agr. Ecosyst. Environ. 233, 262-269. https://doi.org/10.1016/j.agee.2016.09.014.
Villa, M., Somavilla, I., Santos, S.A.P., López-Sáez, J.A., Pereira, J.A., 2019. Pollen feeding habits of Chrysoperla carnea s.l. adults in the olive grove agroecosystem. Agr. Ecosyst. Environ. 283, 106573. https://doi.org/10.1016/j.agee.2019.106573.

Wickham, H., Hester, J., Chang, W., 2019. Devtools: Tools to Make Developing R Packages Easier. R package version 2.2.1. <https://CRAN.R-project.org/pack age $=$ devtools $>$.

White, A.J., Wratten, S.D., Berry, N.A., Weigmann, U., 1995. Habitat manipulation to enhance biological control of Brassica pests by hoverflies (Diptera: Syrphidae). J. Econ. Entomol. 88, 1171-1176. https://doi.org/10.1093/jee/88.5.1171.

Wojciechowicz-Żytko, E., 2019.Attractiveness of some Apiaceae flowers for Syrphidae (Diptera) - pollinators and biological control agents. Grzebelus, D., Barański, R. (Eds.) Proc. II Int. Symp. on Carrot and Other Apiaceae Acta Hortic. ISHS. 1264. <https://doi.org/10.17660/ActaHortic.2019.1264.34>.

Wratten, S.D., White, A.J., Bowie, M.H., Berry, N.A., Weigmann, U., 1995. Phenology and ecology of hover flies (Diptera: Syrphidae) in New Zealand. Environ. Entomol. 24, 595-600. https://doi.org/10.1093/ee/24.3.595. 